\title{
UPSETTING OF ELASTOMERIC MATERIAL. THE RESULTS OF NUMERICAL AND EXPERIMENTAL INVESTIGATIONS
}

\begin{abstract}
This paper presents the results of research aimed at verifying the effectiveness of six selected models of elastomeric materials in which the constants were determined based on the uniaxial tension test. The effectiveness of the selected models (Neo-Hookean, Mooney with two and three constants, Signorini, Yeoh, Ogden) was determined based on a comparison between the results obtained in the experimental upsetting of an elastomeric cylinder and numerical FEM calculations for each model. Cyclic uniaxial tension testing of elastomer samples was employed to determine the stress-strain characteristic for the 18th load cycle. Material constant values were then calculated for each of the studied models based on this characteristic, with simulation of the upsetting process performed using the MARC/Mentat software program.
\end{abstract}

Keywords: elastomers, material models, upsetting, FEM simulation

\section{Introduction}

The majority of sheet metal forming processes are carried out using elastomeric tools. Indeed, taking into account only the aviation industry, it has been estimated that about $60 \%$ of all sheet metal parts are manufactured via the use of rubber tools $[1,2]$. Natural rubbers and elastomers are employed to produce flexible tools used in various technological shaping operations, including drawing, punching and bending. In addition, thanks to their small dimensions and the possibility of obtaining high forces with little deformation, elastomer coil springs have effectively eliminated conventional dies from production. For this

\footnotetext{
${ }^{1}$ Autor do korespondencji/corresponding author: Stanisław Kut, Rzeszow University of Technology, 12 Powstańców Warszawy Ave., 35-959 Rzeszów, tel. 17865 1558, e-mail: stan_kut@prz.edu.pl

2 Grażyna Ryzińska, Rzeszow University of Technology, e-mail: grar@prz.edu.pl

3 Bernadetta Niedziałek, Pratt \& Whitney AeroPower Rzeszów, e-mail: Bernadetta.Niedzialek@pw.utc.com
} 
reason, they are also generally used in the construction of punches for holddown products [2].

For reasons of security and the specialist nature of the production process, the aviation industry requires high levels of both reliability and quality. Therefore, taking into account the various factors and resources of production, the aviation technologist faces a major challenge that requires strong knowledge of the various methods available with which to shape sheet metal. To be able to produce high quality products at the same time as reducing costs and maximising profits, aviation companies typically employ computer simulation during process and product design, which has limited or in some cases superseded the costly trial and error method. However, the effectiveness of computer modelling depends primarily on the adoption of appropriate material models and accurate knowledge of material constants, both of which must be established on the basis of appropriate experimental studies. According to the scientific literature, the correct determination of material constants for elastomers is based on four material tests [3]: the uniaxial tension test, biaxial tension test, planar shear or planar tension test and simple shear test. In practice, performing these tests requires the use of specialised equipment and well-prepared samples. For this reason, the constant supply of elastomers required for the modelling industry is frequently very difficult to achieve and occasionally even impossible. Therefore, the general aim of the research community is to develop material models together with constants that will allow the accurate modelling and subsequent formation of a sheet metal shaping tool or hold-down, without the need for expensive experiments. As the vast majority of elastomeric tools and springs used in presswork are cyclically compressed, the primary test that should be applied first when determining material constants is the uniaxial tension test, which can be performed on a standard testing machine without the need for specialist equipment (tooling). The specific motivation for undertaking the present research was the increasing modelling needs of most technological processes in the industry, characterised as they are by the usage of rubber and elastomers of various properties, and the difficulties of establishing the associated material constants.

The aim of the present paper was to analyse the effectiveness of six selected models of elastomeric materials for which the material constants were determined on the basis of a single material test: the uniaxial tension test.

\section{Elastomer material tools}

Elastomers are widely used in many industries because of their availability, low cost, good formability, efficient damping, energy absorption capacity and long life. Elastomers are a unique material that can be subject to large deformation that is not directly proportional to the required load. Various types of material model have been developed with which to describe elastomer behaviour. For the purpose of the present study, the following six models were selected for 
analysis: Neo-Hookean, Mooney (2) (with two constants), Mooney (3) (with three constants), Signorini, Yeoh and Ogden (with number of components N =1, 2 and 3). The Neo-Hookean model, which is used mostly for modelling materials undergoing tension testing, is one of the simplest models employed to describe hyperelastic elastomeric materials. The strain energy function for this model takes the form:

$$
W=C_{10}\left(\lambda_{1}^{2}+\lambda_{2}^{2}+\lambda_{3}^{2}-3\right)
$$

where: $\lambda_{i}=1+\varepsilon_{i}$; and $\varepsilon_{i}=\left(\frac{\Delta L_{i}}{L_{i}}\right)$ - contractual strain.

The incompressibility assumption: $\lambda_{1} \lambda_{2} \lambda_{3}=1$. The equations for stress and shear stress take the form:

$$
\sigma=\frac{\partial W}{\partial \lambda}=\sigma(\varepsilon) ; \tau=\frac{\partial W}{\partial \lambda}=G \gamma
$$

As the Neo-Hookean model is inefficient for the modelling of biaxial stress, the latter is typically calculated via the Mooney model, also known as the Mooney-Rivlin model. These models differ from the Neo-Hookean as their formulae include two or three material constants that must be determined on the basis of appropriate experimental study. The basic premise of these models is the assumption of incompressibility and isotropy, as well as the assumption of the validity of Hooke's law in the state of pure shear. The dependence of the function describing the strain energy for the Mooney model takes the form:

$$
W=C_{1}\left(\lambda_{1}^{2}+\lambda_{2}^{2}+\lambda_{3}^{2}-3\right)+C_{2}\left(\frac{1}{\lambda_{1}^{2}}+\frac{1}{\lambda_{2}^{2}}+\frac{1}{\lambda_{3}^{2}}-3\right)
$$

For pure shear:

$$
\begin{aligned}
& W=\left(C_{1}+C_{2}\right)\left(\lambda_{1}^{2}+\frac{1}{\lambda_{1}^{2}}-2\right)=\left(C_{1}+C_{2}\right) \gamma^{2} \\
& \tau=\frac{d W}{d \gamma}=2\left(C_{1}+C_{2}\right) \gamma
\end{aligned}
$$

Hence: $G=2\left(C_{1}+C_{2}\right)$

$$
\sigma=2\left(\lambda-\frac{1}{\lambda^{2}}\right)\left(C_{1}+\frac{C_{2}}{\lambda}\right)
$$

Using the tensor formula:

$$
\begin{aligned}
& \mathrm{I}_{1}=\lambda_{1}^{2}+\lambda_{2}^{2}+\lambda_{3}^{2} \\
& \mathrm{I}_{2}=\lambda_{1}^{2} \lambda_{2}^{2}+\lambda_{2}^{2} \lambda_{3}^{2}+\lambda_{3}^{2} \lambda_{1}^{2}
\end{aligned}
$$




$$
\mathrm{I}_{3}=\lambda_{1}^{2} \lambda_{2}^{2} \lambda_{3}^{2}
$$

where: $\mathrm{I}_{1}, \mathrm{I}_{2}, \mathrm{I}_{3}$ are strain invariants.

From the assumption of incompressibility, $\mathrm{I}_{3}=0$ and hence $\mathrm{W}=\mathrm{W}\left(\mathrm{I}_{1}, \mathrm{I}_{2}\right)$. For the Mooney-Rivlin model, the strain-energy equation based on the above assumptions is shown below:

$$
W=C_{10}\left(I_{1}-3\right)+C_{01}\left(I_{2}-3\right)
$$

while the strain-energy function in Mooney-Rivlin material model with three parameters is as follows:

$$
W=C_{10}\left(I_{1}-3\right)+C_{01}\left(I_{2}-3\right)+C_{11}\left(I_{1}-3\right)\left(I_{2}-3\right)
$$

The Signorini model is a modification of the Mooney-Rivlin model in which the strain energy function for three material constants takes the form:

$$
W=C_{10}\left(I_{1}-3\right)+C_{01}\left(I_{2}-3\right)+C_{20}\left(I_{1}-3\right)^{2}
$$

The Yeoh model is applicable to a considerably larger range of deformation, with the strain energy function written as:

$$
W=C_{10}\left(I_{1}-3\right)+C_{20}\left(I_{1}-3\right)^{2}+C_{30}\left(I_{1}-3\right)^{3}
$$

Finally, the Ogden model is often used to model non-linear stress-strain, mainly for rubber components with low compressibility. This model differs from the others described above as it has a number of variants based on the number of ingredients in the function [3].

$$
W=\sum_{n=1}^{N} \frac{\mu_{n}}{\alpha_{n}}\left[J^{\frac{-\alpha_{n}}{3}}\left(\lambda_{1}^{\alpha_{n}}+\lambda_{2}^{\alpha_{n}}+\lambda_{3}^{\alpha_{n}}\right)-3\right]+4,5 K\left[J^{1 / 3}-1\right]^{2}
$$

where: $\mu_{\mathrm{n},} \alpha_{\mathrm{n}}$ are material constants; and $\mathrm{J}=\lambda_{1} \lambda_{2} \lambda_{3}$.

\section{Uniaxial tension test}

The typical dumbbell samples used in the cyclic tensile tests were $5 \mathrm{~mm}$ thick and $10 \mathrm{~mm}$ wide, and were composed of an elastomer with a hardness of $90{ }^{\circ} \mathrm{ShA}$ (Fig. 1a). Tension testing was performed on a Zwick/Z030 ROELL testing machine, whose workspace and a tension sample is shown in Fig. 1b. Sample stress-strain characteristics were obtained after 18 load cycles (Fig. 2), with the values then inserted into the MARC/Mentat 2014 commercial software program. Based on these stress-strain characteristics, material constants were 
calculated for each of the tested models: Neo-Hookean, Mooney with two and three constants, Signorini, Yeoh and Ogden, as shown in Tables 1 and 2.

b)

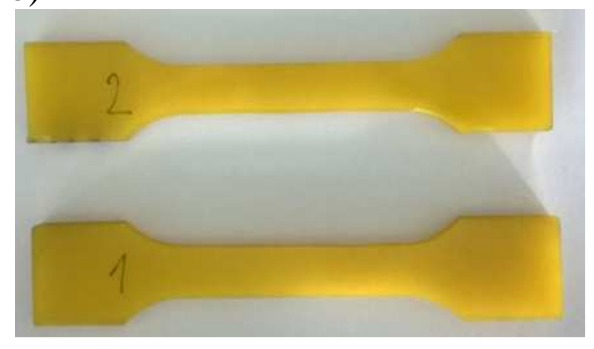

a)

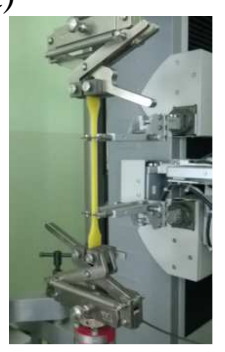

Fig. 1. Samples used in the uniaxial tension tests (a) and sample during the uniaxial tension test (b)

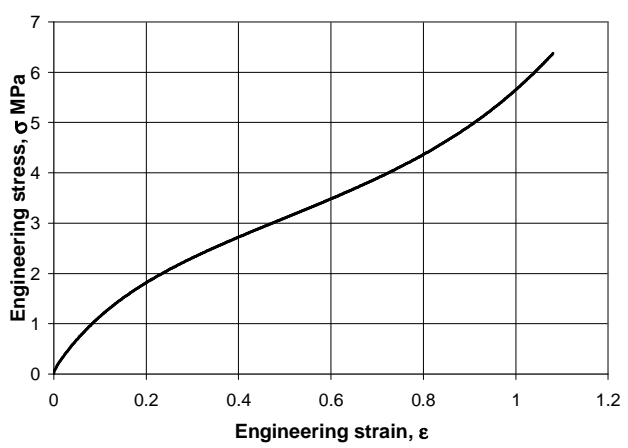

Fig. 2. Stress-strain curve for the 18 th load cycle

Table 1. Material constants obtained from the uniaxial tensile test for phenomenological models

\begin{tabular}{|l|l|c|c|c|c|c|}
\hline \multirow{2}{*}{ No. } & \multirow{2}{*}{ Model name } & \multicolumn{6}{|c|}{ Material constants } \\
\cline { 3 - 7 } & & $\mathrm{C}_{10}$ & $\mathrm{C}_{01}$ & $\mathrm{C}_{11}$ & $\mathrm{C}_{20}$ & $\mathrm{C}_{30}$ \\
\hline $\mathrm{I}$ & NEO-HOOKEAN & 1.568 & - & - & - & - \\
\hline II & MOONEY (2) & 0.787 & 1.226 & - & - & - \\
\hline III & MOONEY (3) & -2.89 & 5.523 & 0.779 & - & - \\
\hline IV & SIGNIORINI & -1.877 & 4.414 & - & 0.326 & - \\
\hline V & YEOH & 1.958 & - & - & -0.484 & 0.135 \\
\hline
\end{tabular}

Table 2. Material constants obtained from the uniaxial tensile test for the Ogden model

\begin{tabular}{|c|c|c|c|c|}
\hline \multirow{3}{*}{ No. } & \multirow{3}{*}{ Model name } & \multirow{2}{*}{$\begin{array}{c}\text { Number } \\
\text { of components }\end{array}$} & $\begin{array}{c}\text { Modulus } \\
\mu_{\mathrm{n}}\end{array}$ & $\begin{array}{c}\text { Mxponent } \\
\alpha_{\mathrm{n}}\end{array}$ \\
\cline { 3 - 5 } & & 1 & -1.7794 & -5.1831 \\
\hline \multirow{3}{*}{ VI } & \multirow{3}{*}{ OGDEN } & \multirow{2}{*}{2} & -1.184 & 3.706 \\
\cline { 3 - 5 } & & \multirow{3}{*}{3} & -2.246 & -7.103 \\
\cline { 3 - 5 } & & 96.7923 & -0.12575 \\
\cline { 3 - 5 } & & -0.14822 & 3.09525 \\
\cline { 3 - 5 } & & & -5.46016 & -4.42401 \\
\hline
\end{tabular}




\section{Cyclic upsetting test}

In order to obtain experimental data necessary to verify the results of the numerical calculations, pre-prepared samples were subjected to cyclic upsetting tests using a Zwick/Z030 ROELL testing machine. The tested samples were cylindrical, with diameter $d=11.8 \mathrm{~mm}$ and height $\mathrm{h}_{0}=19 \mathrm{~mm}$ (Fig. 3a). In order to eliminate the impact of sliding friction and to stabilise contact conditions, sandpaper was inserted between the contact surfaces of the sample and the upsetting tool (Fig. 3b). Force characteristics were obtained for the same load cycle as in the uniaxial tension tests, with these values then used to analyse the convergence of the results obtained using the selected material model.

a)

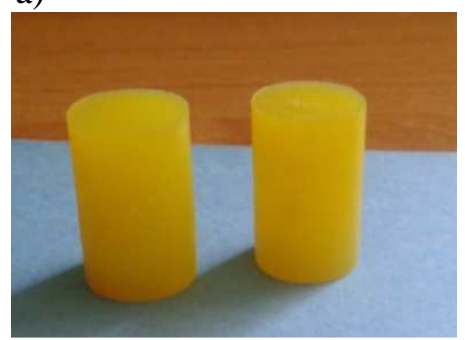

b)

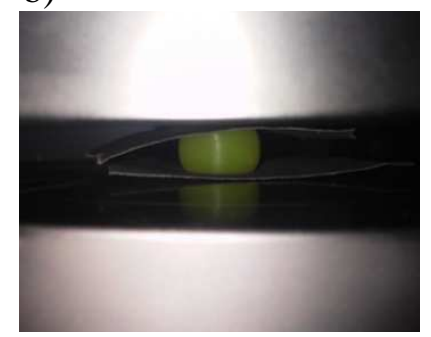

Fig. 3. Elastomeric samples: a) before upsetting, b) during upsetting to $65 \%$

\section{Numerical modelling of the upsetting process}

A numerical simulation of the upsetting process was performed using MSC MARC/Mentat 2014 in order to analyse nonlinear and contact issues. The numerical model was constructed based on the experimental model. Due to the usage of sandpaper between the sample surface and tool, a "glue" was assumed applied at the contact. The sample model was performed based on discretisation on 32832 hex 8 finite elements of type 84 [4]. In the simulation, the sample was upset by three-quarters of its height as in the experiment. Deformation during the upsetting of the elastomeric sample was calculated using the following equation:

$$
\varepsilon_{\mathrm{h}}=\left(1-\frac{\mathrm{h} 1}{\mathrm{~h} 0}\right) \cdot 100 \%=\frac{\mathrm{s}}{\mathrm{h} 0} \cdot 100 \%
$$

In this case $\varepsilon_{h}=65 \%$, where $h_{1}$ is the height of the sample after deformation, $\mathrm{h}_{0}$ is the initial sample height and $\mathrm{s}$ is the movement of the upsetting tool.

\section{Convergence analysis of numerical simulation experiment}

In order to compare the simulation results for each of the material models with the experimental results, a graph was created summarising the experimental 
force as a function of the degree of sample deformation and the calculated courses for the examined material models (Fig. 4).

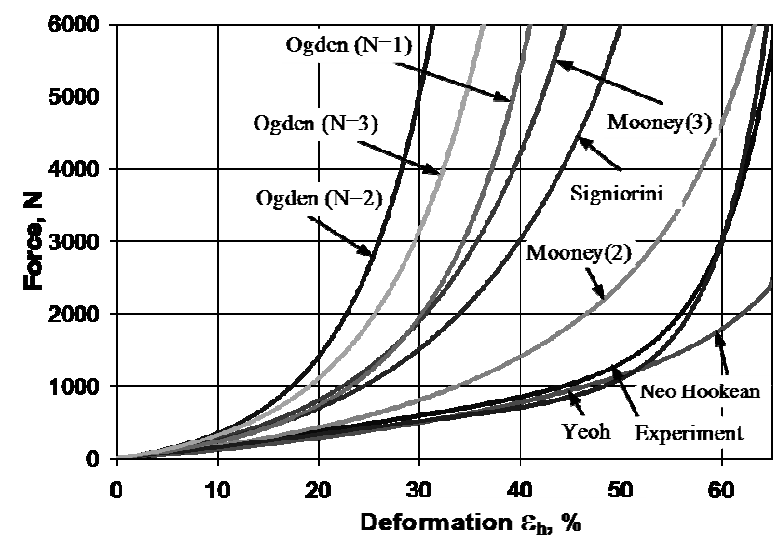

Fig. 4. Experimental and calculated characteristics of the upsetting force as a function of sample deformation for each of the models tested

Analysis of the chart above reveals that the choice of material model has a huge impact on the convergence of the numerical simulation with the conducted experiment. Model efficacy can be characterised in terms of two categories. The first includes those material models that display almost complete correlation in the specified range of deformation. In the range $\varepsilon_{\mathrm{h}}=0$ to $17 \%$, the Mooney (2) model output followed the experimental results almost exactly, followed by the Yeoh $\varepsilon_{\mathrm{h}}=(0-12 \%)$ and Neo-Hookean $\varepsilon_{\mathrm{h}}=(0-6 \%)$ models. The remaining models were poorly correlated with the experimental results at values of $\varepsilon_{\mathrm{h}}>2 \%$. The second category concerns the comparison of the models with the greatest correlation as across the total range of possible deformation. This condition was met best by the following models: Yeoh, $\varepsilon_{\mathrm{h}}=(0-62 \%)$ and Neo-Hookean, $\varepsilon_{\mathrm{h}}=(0-$ 45\%). The remaining models, especially the Ogden, Signorini and Mooney, exhibited a large discrepancy between simulation and experimental data.

\section{Conclusions}

The presented results demonstrate that the selection of elastomer material model has a significant impact on the convergence between simulation and experimental studies. Here we have shown that such correlation is highly dependent on the degree of upset, expressed in terms of the amount of deformation $\varepsilon_{\mathrm{h}}$. Therefore, when modelling technological issues associated with the usage of flexible tools, it is essential to take the material model selected into account, whose convergence with experimental data must be at least satisfactory with respect to distortion occurring during the actual production process. 
The present research has shown that for the modelling of elastomeric cylinder upsetting in a deformation range of $62 \%$, the best results were obtained by the Yeoh model. Based on the obtained data, it can thus be concluded that although setting constants in elastomer material models based solely on one material test (e.g. the uniaxial tension test) can provide satisfactory results, the appropriate material model for the actual amount of deformation must be selected.

\section{References}

[1] Ali A., Hosseini M., Sahari B.B.: A review of constitutive models for Rubber-Like materials, American J. Eng. Applied Sci., 3 (2010) 232-239.

[2] Ramezani M., Rapin Z. M.: Rubber-pad forming processes: Technology and applications. Woodhead Publishing, 2012.

[3] MSC.Software: Nonlinear Finite Element Analysis of Elastomers.

[4] MSC.Software, MSC.Marc, vol. B, Element Library, ver. 2014.

\section{SPECCZANIE MATERIAEU ELASTOMEROWEGO. WYNIKI BADAŃ NUMERYCZNYCH I EKSPERYMENTALNYCH}

\section{Streszczenie}

W pracy przedstawiono wyniki badań mających na celu sprawdzenie skuteczności sześciu wybranych modeli materiałów elastomerowych, w których stałe wyznaczono na podstawie próby jednoosiowego rozciągania. Skuteczność wybranych modeli materiałowych (Neo-Hookean, Mooney z dwiema i trzema stałymi, Signiorini, Yeoh, Ogden) określano na podstawie porównania wyników uzyskanych w eksperymentalnej próbie spęczania elastomerowego walca z wynikami obliczeń numerycznych MES przeprowadzonymi dla poszczególnych modeli. Na podstawie cyklicznej próby jednoosiowego rozciągania elastomerowej próbki sporządzono charakterystykę naprężenie-odkształcenie dla 18-tego cyklu obciążenia. W oparciu o otrzymaną charakterystykę obliczono wartości stałych materiałowych dla badanych modeli oraz wykonano symulacje procesu spęczania z wykorzystaniem systemu MARC/Mentat.

Słowa kluczowe: elastomery, modele materiałowe, spęczanie, symulacja MES

DOI: $10.7862 / \mathrm{rm} .2015 .32$

Otrzymano/received: $2.10 .2015 \mathrm{r}$.

Zaakceptowano/accepted: $25.11 .2015 \mathrm{r}$. 